\title{
NATURALLY AVAILABLE ANTI-MICROBIAL IN PLANTS: A GENERAL OVERVIEW
}

\author{
MstNushrat Yiasmin ${ }^{1}$, AL-Ansi Waleed ${ }^{1,2}$, Xiao Hua $^{1 *}$ \\ ${ }^{1}$ School of Food Science and Technology, State Key Laboratory of Food Science and Technology, \\ Jiangnan University, 1800 Lihu Avenue, Wuxi 214122, China. \\ ${ }^{2}$ Department of Food Science and Technology, \\ Faculty of Agriculture, Sana'a University, Sana'a, Yemen. \\ *Corresponding Author: (X. Hua) huaxiao@jiangan.edu.cn \\ DOI: https://doi.org/10.51193/IJAER.2021.7109
}

\begin{abstract}
The secondary metabolites that can be present in plants, animals, and microorganisms are natural antimicrobials. In natural antimicrobial research, however, plants, especially herbs and spices, are given more attention; this chapter focuses on new fruit and vegetable discoveries. In addition to bacteriocins, microorganisms which are used in food fermentation often develop various antimicrobial metabolites, including organic acids, hydrogen peroxide, ethanol, and diacetyl. Animal products such as tissue, milk and eggs contain various antimicrobial agents, mostly in the form of peptides (polypeptides). In certain cases, to be tested or added to food products, natural antimicrobials are extracted and purified. Extraction and purification can alter the chemical structure of and influence the functionality of natural antimicrobials. Thus, in order to avoid potential modification or degradation of active ingredients, an extraction method with minimal processing such as juice or mechanical direct extraction seems to be more promising. The behavior of natural antimicrobials may also be affected by the original source, harvest time and growth stage. These natural antimicrobial compounds could be affected by food components, processing, and storage in food applications. Growing consumer fears regarding chemical antimicrobials, on the other hand, and increasing resistance of pathogenic microbes have drawn the scientific community's attention to studies on the possible antimicrobial activity of natural products. Natural antimicrobials are normally recognized as safe and the most promising solution appears to It is for microbial resistance and might better meet the demands of consumers for healthy foods. Recent perspectives on the antimicrobial activities of natural plant products, extraction methods, modes of action and factors affecting antimicrobial activity have been addressed in this review article.
\end{abstract}

Keywords: Antimicrobial, natural products, plant, microorganisms 
International Journal of Agriculture and Environmental Research

ISSN: 2455-6939

Volume: 07, Issue: 01 "January-February 2021"

\section{INTRODUCTION}

Natural products are chemical compounds or substances that are formed or found in nature by a living organism and have pharmacological or biological activity [1]. Multiple primary and secondary metabolites are produced by living organisms. Primary metabolites have an essential role in the body, while secondary metabolites may have important functions or may simply be waste products for their manufacturers. Secondary metabolites, however, can also have properties that are useful for humans. They can be used as medications for human diseases in many cases, such as cancer, bacterial infections, inflammation and many other diseases [2-4]. However, because of their antimicrobial activity, a variety of these secondary metabolites have been reported. In most species, secondary metabolites with antimicrobial activity can be found, including: (1) plants such as fruits, vegetables, nuts, herbs and spices, (2) animal sources such as milk, eggs and tissues, and (3) microorganisms such as fungi and bacteria. Due to the growing concern among consumers regarding chemical preservatives, natural antimicrobials are being given more attention. Even though chemical preservatives are licensed by government agencies for human use, many of these preservatives are still threatening our health. Thus, more attention has been paid by the scientific community to the possible antimicrobial activities of natural products. On the other hand, there are increasing rates of antibiotic resistance to chemical preservatives of some foodborne disease-related pathogens $[5,6]$. The most promising solution to many of the growing concerns about antibiotic resistance seems to be natural antimicrobials and could produce better results than antimicrobials from combinatorial chemistry and other synthetic procedures [7]. Therefore, there is a strong demand for novel types of effective and healthy antimicrobial compounds that could protect foods from contamination and consumers from infection.

A significant number of studies investigating the antimicrobial function of natural products have been performed in recent years. There is more attention given to plants, particularly herbs and spices. There are now over 1340 plants with established antimicrobial activity, and more than 30,000 plant-isolated antimicrobial compounds [8]. In addition, comprehensive research has explored possible food uses for natural antimicrobial agents against foodborne pathogens in food products and animal feed.

This paper discusses the latest studies on natural plant and microorganism antimicrobial compounds that could be used in food products to control spoilage and pathogenic microorganisms. In addition, methods of extraction, mechanism of action, and factors affecting the activity of antimicrobials are discussed.

\section{METHODOLOGY}

This paper reviews the experience of the scholar, current hypotheses and modals in narrative terms. The authors include the data here based on the reviewing concern book, science journal, cutting of 
national and foreign newspapers as well as the websites of the concern. Instead of quantitative level, findings are based on qualitative.

\section{THE PLANT'S ANTIMICROBIAL PRODUCTS}

An array of secondary metabolites that can be found in nutritious, medicinal, and herbal plants and their essential oils (EOs) [9] are produced by plants. Plant secondary metabolites are widely researched as promising safe ingredients or agents that control human disease. The numerous benefits of these secondary metabolites include antimicrobial properties against pathogenic and spoiling microbes [7]. Plant-based natural antimicrobials have been known for decades, but have only been scientifically confirmed in the last 30 years $[3,10]$.

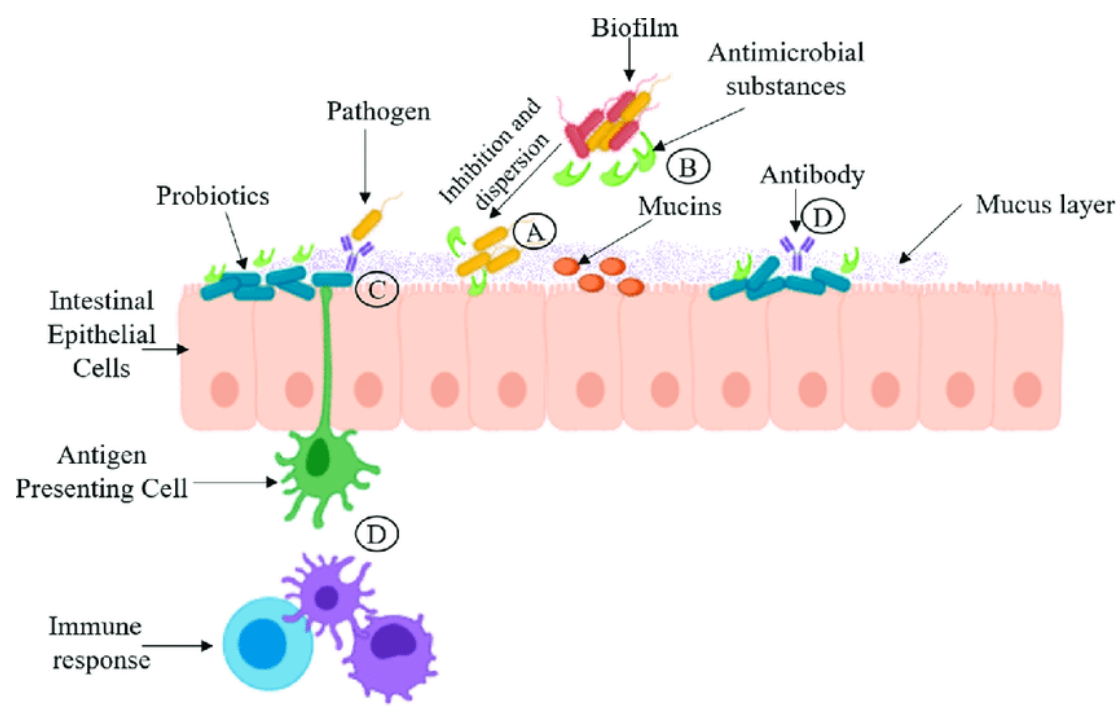

Fig. 1: Mechanisms of action of probiotics. (A) Competitive.

Therefore, a growing interest in discovering natural antimicrobials for use in food products for the prevention or prevention of Microbial growth is hindered and shelf life has been extended [11, 12]. In a single molecule, the presence of both antioxidant and antimicrobial properties allows them more efficient and ideally suited as food preservatives. Overall, plants have a much greater Grampositive inhibition effect than Gram-negative bacteria. The existence of broad-spectrum antibiotic compounds or simply general metabolic toxins can be suggestive of activity against both types of bacteria [13]. In plants, the antimicrobial effectiveness of components depends on the chemical structure and concentration of the active components. In plants with antimicrobial effects, different chemical components are present, including saponin, flavonoids, thiosulfinates, glucosinolates, phenolics, and organic acids. However, phenolic compounds such as terpenes, aliphatic alcohols, aldehydes, ketones, acids, and isoflavonoids are the key components in plants with antimicrobial 
International Journal of Agriculture and Environmental Research

ISSN: 2455-6939

Volume: 07, Issue: 01 "January-February 2021"

activity [9]. For example, it was suggested that the antibacterial activity of 46 spice and herb extracts was correlated with the presence of phenolic constituents [14]. All the spices tested have a strong antibacterial effect against Bacillus cereus, the authors have stated, Listeria monocytogenes, Staphylococcus aureus, Salmonella anatum and Escherichia coli. It was also proposed that the antimicrobial activity of red cabbage was due to the fact that red cabbage is a rich source of anthocyanins [15], a phenolic compound. Wider antimicrobial properties are found in phenolic compounds of EOs, such as citrus oils derived from lemon, olive oil (oleuropein) and tea tree oil (terpenoids), orange and bergamot. Nonphenolic oil compounds, which are effective against both Gram-positive and Gram-negative groups, are increasingly published, however, Oregano, cloves, cinnamon, citrus fruits, garlic, cilantro, rosemary, parsley, lemongrass, muscadine, and sage [1620]. Some essential oils, such as allyl isothiocyanate and garlic oil, contain nonphenolic constituents that are more effective or very effective against Gram-negative bacteria. In fruits, berries, nuts, seeds, stems, bulbs, and leaves [21], saponin and flavonoids are found. Saponins and flavonoids derived from plants such as Bersama engleriana (Melianthaceae) have been shown to have antimicrobial activity when extracted from roots, bark, leaves and wood [21-24]. A strong antimicrobial activity against Gram-negative bacteria has also been demonstrated by thiosulfinates. Glucosinolates are secondary metabolites of mustard, cabbage, cauliflower, brussel sprouts, broccoli, kohlrabi, kale, horseradish, and radishes, which occur in many plant species[10, 25]. Important antimicrobial activity against Gram-positive bacteria, Gram-negative bacteria and fungi with a direct or synergistic effect in combination with other compounds has been documented in glucosinolate hydrolysis products [10]. In herbs and spices (rosemary, sage, basil, oregano, thyme, marjoram), antimicrobial compounds in plant materials are commonly found in, Cardamom and clove), seed and leaves (grape grains, caraway, pheen, nutgem, tomato, cabbage and olive leaves) and fruit and vegetables (guava, xoconostle, pepper and clove) [8, 9].

\subsection{Herbs and spices}

Human herbs and spices have been used for various purposes, including antimicrobials, since ancient times. Herbs and spices are the most common natural antimicrobials in the food industry and their extracts. They typically contain EOs with antimicrobial activities that are well known. Plant EOs are typically vapor-induced and are able to enter microbial pathogens in the fluid and gas phases [26]. Several studies have shown the antimicrobial effect of EOs in relation to various foodborne and spoilage pathogens. However, $\mathrm{pH}$, storage temperature, oxygen content, EO concentration and active ingredients are the main elements for EO efficiency [16, 18, 27, 28]. The most effective inhibitors to $\mathrm{S}$ growth have been found in lemongrass, cinnamon and geraniol EOs. E. entitidis. Coli and Harmless Listeria [29]. An E may be used for Mustard EOs. O157:H7 and S coli. [31]. [23]. The non-phenolic volatile compound Allyl isothiocyanate present at low concentrations in the Crucifereae family actually inhibits a variety of pathogenic microorganisms 
[30]. Antimicrobial effects against E were reported by Oregano Eos. Okay, S. Core, B. Subtilis and Cerevisiae [4] Saccharomyces. Herbs and spices can have a direct or indirect effect as antimicrobial anti-gram-positive and gram-negative agent to prolong food shelf-life. Sour plants and herbs and oregano, clova, cinnamon, citrus fruits and garlic spices coriander, rosemary, parsley, successfully used either alone or in combination with other preservation methods, the lemongrass, sage, and vanillin $[16,17,31,32]$ have been used.There were also fewer antimicrobial properties of other spice such as Ginger, black pepper, red pepper, chili powder, cumin and curry powder [18]. In order of clove $>$ kaffi $>\mathrm{r}$ lime skins $>$ Cumin $>$ cardamom $>$ coriander $>$ nutmeg $>$ mace $>$ ginger $>$ garlic $>$ holy basil $>$ Kaffir lime skins [33] was reported antibacterial activity in various spices that were tested against the salmonella and other enterobacteria. Bacteriostatic and bactericidal properties of Oregano and Thyme EOs are important, which irreversibly damaged $E$. coli at this bactericidal concentration of Oregano EO. E. coli O157:H7 in 1 min [34]. The antimicrobial properties of oregano and thyme EO were found to be greater as clove and bay [34].

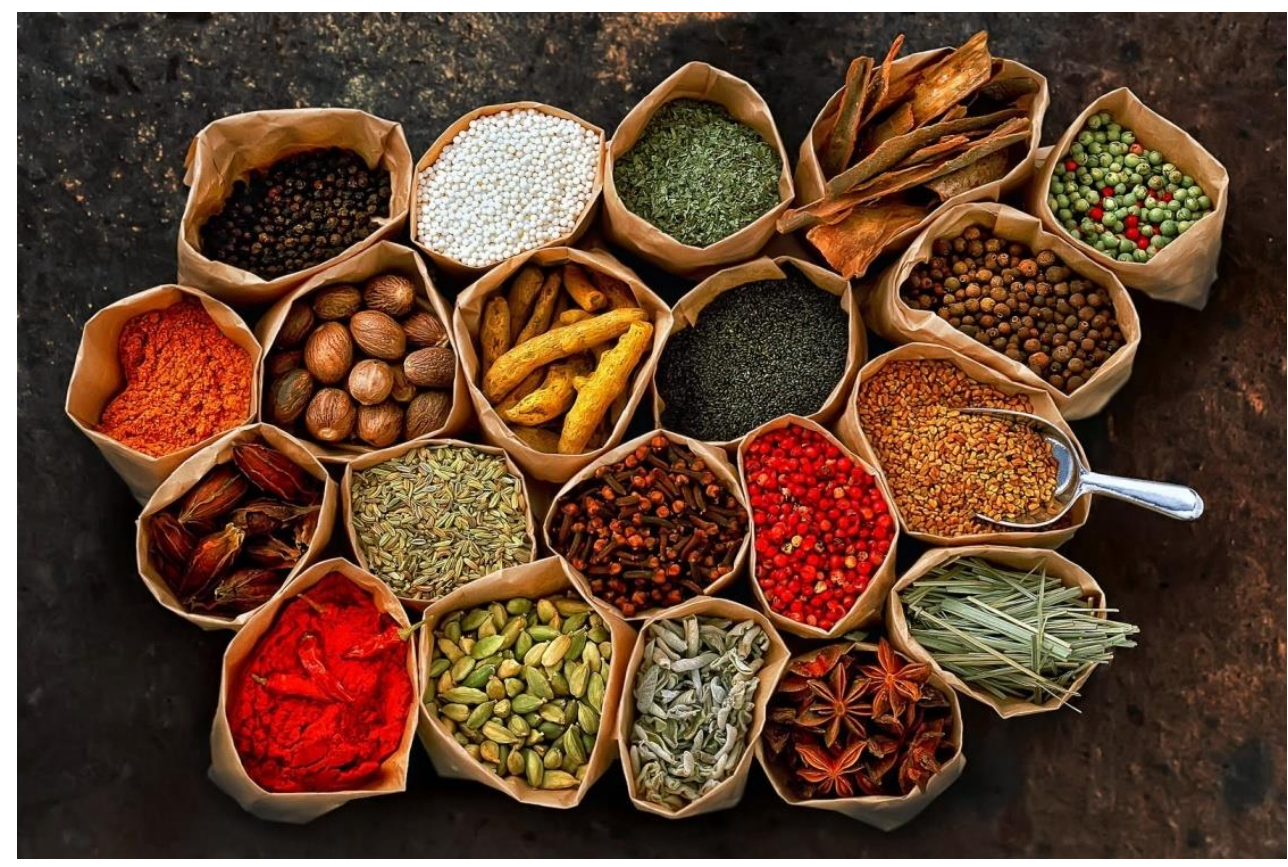

Fig. 2: Herbs and spices (https://cn.bing.com/images/search)

\subsection{Fruits and vegetables}

Although herbs and spices for antimicrobial activity have been well investigated and reported, more attention is now being focused on fruit and vegetables. There is also a well-known antimicrobial effect of many fruits and vegetables against various pathogens and spoilage microbes. In general, fruit and vegetables contain phenolics and organic acids proven to have 
International Journal of Agriculture and Environmental Research

ISSN: 2455-6939

Volume: 07, Issue: 01 "January-February 2021"

antimicrobial activity. For example, the antimicrobial activity in Capsicum was reported to be due to the phenolic compound and 3-hydroxycinnamic acid (coumaric acid) [38]. Flavonoids from bergamot peel, a byproduct of citrus fruit processing, was found to be active against Gramnegative bacteria (Escherichia coli, Pseudomonas putida, Salmonella enterica) and the antimicrobial potency of flavonoids was increased after enzymatic DE glycosylation [20]. Antibiotic activity was investigated for fruit and veggies including: aronianberry, bell pepper, beet, blackberry, blueberry, broccoli, carrot, turkey, cranberry, garlic, ginger, grape, red onion, rhubarb, rutabaga, mango, spinach, strawberry and green tea [39].In the case of Staphylococcus epidermidis and Klebsiella pneumonia, it was confirmed that all green vegetables do not have anti-bacterial activity, whereas all purple and red vegetables and fruit juices showed antimicrobial activity. The growth of $\mathrm{E}$ was inhibited by pomegranate juice. O157:H7 coli [40]. Also mentioned was the methanol extract of grenade peels antimicrobial activity against Gram-positive bacteriaThe existence of phenolics and flavonoids is responsible for gram-negative bacteria and fungi [41]. Antibacterial effects against spoilage and disease, including Aeromonas hydrophile, B of pomace grapes (Cultivar Emir and Kallecikkarasi). Enterococcus faecalis, E, Cereus, Aerogenic Enterobacter. Coli, E. Coli, E. O157:H7, Mycobacterium smegmatis, Pseudomonas aeruginosa, Proteus vulgaris, Pseudomonas fluorescenes, Salmonella entitidis, S. Mermaids, C., S. The evaluation was performed for aureus and Yersinia enterocolitica [42]. With the exception of Y enterocolitica, which was not inhibited at 2.5 percent, all the test bacteria were inhibited with 2.5 , 5, 10 and 20 percent extract concentrations. E coli O157:H7 was the most vulnerable to grape pomace extract in the screened bacteria. Direct guava extract has been reported to have a significant inhibition of E development. O157:H7 coli and Salmonella [43], respectively. Direct xoconostle pear extract has been documented to produce an active natural $\mathrm{E}$ anti-microbial effect. O157:H7 coli in medium laboratory [44]. In xoconostle pears, the antimicrobial activity was possibly attributed to the phenol compound, ascorbic acid, and betalans. Betalains are active compounds in a plant where antioxidant activity has been recorded [45-47] but their antimicrobial effects have yet to be verified. Capsicum annuum extract antimicrobial function S. The concentration of typhimurium in beef (ATCC14028) was $1.5 \mathrm{~mL} / 100 \mathrm{~g}$ [48]. C. Also, annuum extracts inhibit L growth have been published. monocytogenic material, S. Horned, S. And B. and Typhimurium. [38]. [4]. The aqueous Acetone extract of the fruit pulp and peel (Cydonia oblonga Miller) was more antimicrobial in effect on the growth of bacteria than the fifteenth pulp, primarily chlorogenic acid, as a result of its high concentration of phenolic content [11]. Garlic extract (Allium sativum) also has a wide spectrum of action with antimicrobials. A compound of organosulfur in garlic allicin serves as a growth inhibitor in grams-positive as well as gramsnegative, like E-bacteria. Coli, Salmonella, Straptococcus, Staphylococcus, Proteus and Pylori Helicobakter [49,50]. Alilicine, diallyl thiosulfine acid or diallyl disulphide can induce antibacterial activity in garlic [51]. Moreover, compounds of organosulfur in garlic may be higher 
antimicrobial than compounds of garlic phenolics [3]. Comparing phenolic compounds with Campylobacter jejuni, the bactericidal properties of garlic-derived organosulfur composite were more effective [4]. The extract of garlic has good antibacterial activity against E. Aeromonas hydrophile, coli, salmonella. Garlic extract demonstrated against all E serogroups antibacterial activity. While coli, enterohemorrhagic E. Coli and enterotoxigenic E (O157 serogroup). Coli was considered more vulnerable to garlic extract (serogroup O8) [52]. In Asian cooking, Chinese chive which belongs to the same family as garlic is an essential component. The strong antimicrobial effect on $\mathrm{E}$ in Chinese chive has been documented. Colli (Pichia membranaefaciens CCRC 20859) and leaf (Yeast)[53]. Chinese chive crude extract contains sulfur compounds which have been found to be effective against salmonella growth and can also be used in foodstuffs to prevent this pathogen growth [54]. Srinivasan et al., (2001) tested 50 different gram-positive plants, Gramnegative plants and fungi. The authors of all the plants studied reported the promising effect of allium sativum, an onion genus species, on all tested pathogenic bacteria and funguses. The black pepper, clove, geranium, nutmeg, oregano and thyme volatile oils have been antibacterial to 25 different types of tested bacteria with different levels of growth inhibition [35].The spinach (Spinaceaoleracia), pumpkin (cucurbita pepo), suran (Amorphophaluscampanulatus) and ghuiya (Colocasia esculenta) methanol extracts have shown a moderate to strong anti-microbial effect with several Gram-positive and Gram-negative bacteria [55]. Among all E extracts, Methanol spinach extract was the most effective. Coli. Coli. More productive than its aqueous extracts were methanol extracts. There is high risk of high antimicrobial activity in fruits and vegetables rich in phenolics and organic acid.

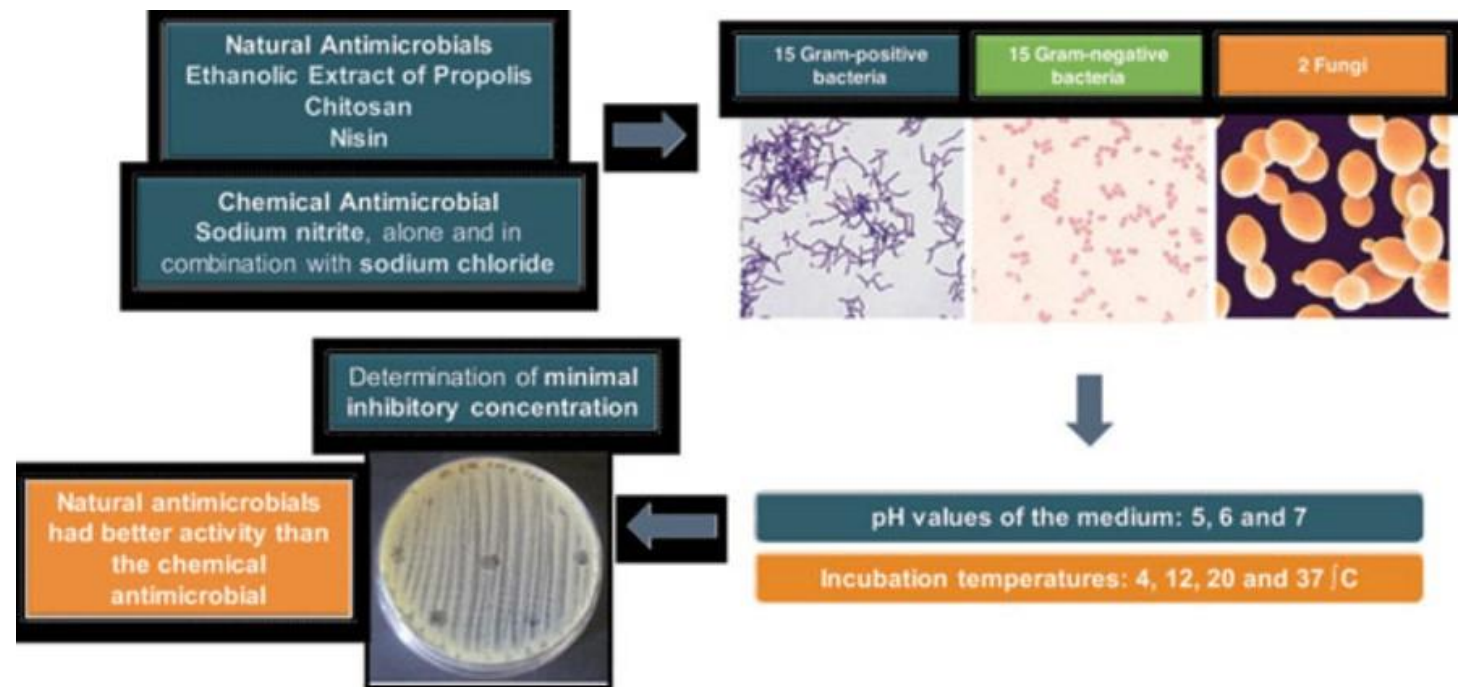

Fig. 3: Natural antimicrobials for food (https://cn.bing.com/images/search) 
International Journal of Agriculture and Environmental Research

ISSN: 2455-6939

Volume: 07, Issue: 01 "January-February 2021"

\subsection{Seeds and leaves}

Antimicrobial activity can also be demonstrated by seeds and leaves containing EOs and various phenolic compounds. Crude EOs such as dill (Anethumgraveolens L.), coriander (Coriandrum sativum L. seeds), coriander (C. sativum L immature leaves) and eucalyptum (Eucalyptus dives) were found to be effective at concentrations 0.5 percent (vole/vol) against several bacteria and one yeast [56]. Extracts of grape-seeds are widely regarded as a healthy food additive and are known for their antimicrobial and antioxidant activity [57-59]. Antimicrobial activity is caused by the partial hydrophobic nature of the compounds in the grape seed extract from grape phenolic grapes $[59,60]$. The inhibitory activity against $\mathrm{E}$ of extract of grape seed and pine bark extract. O157:H7, Typhimurium and Typhimurium and L. In ground beef, monocytogenes was examined. It appears that these naturally occurring extracts can be used with other methods of retaining the pathogens and improve the quality of soil beef [57]. Extract of grape seeds with nisin, malic acid and EDTA have shown good anti-L production activity. E and monocytogenes. O157:H7 coli [60]. Water extracts from muscadin seeds have also shown high levels and strong antimicrobial activity against E. Phenolic compounds have been identified. O157:H7 coli [61]. Pathogenic bacteria and fungi have been tested for olive leaf. With 0.6 percent (w/v) of olive leaf extraction water almost all bacterial cells were killed within a span of 3 hours. The dermatophytes and Candida albicans had to be killed by 1.25 percent and 15 percent (w/v) of olive leaf extract [62]. Antibacterial and antifungal extract of olive leaves have been reported [63] as well. The author also pointed to the phenolic compounds such as: caffeic acid, verbascoide, oleuropine, luteoline 7-Oglucoside, rutin, apigenin 7-O glucose, and luteolin 4'-O-glucoside as antifungal and antibacteria activities for the olive leaves [63]. The author therefore proposed the possible use as nutraceuticals of extract from olive leaves, in particular as a source of phenolic compounds. Methanol extract of Tagetes minuta L flora, stem and leaf has been found to be selective against all E. coli, Pseudomonas Aregnosa, S typhi, S. Clebsiella pneumoniae Aureus, Viridian Streptococcus, B. Sheepskins, B. Multocida with MIC range of 4-100 mg/mL [64] and subtilis with Pasteurella multocida. The authors proposed that the presence of alkaloids, tannins and flavonoids is responsible for this antimicrobial effect. Grampositive bacteria, gram-negative bacteria and candida-albicans were assessed for the antimicrobial activity of rubuschamaemore leaf [65]. The authors stated that certain gram-positive Bacteria are involved in the leafs of Rubuschamaemor. Cassia alata extract of the leaves has been reported to display S activity. but not to impact E. Aereus. [66]. coli. The inhibition activity against Vibrio parahaemolyticus was demonstrated through methanol extract of the Orthosiphon stamineus plant [67]. Due to the high concentration of rosmarinic acid the antibiotic effects of the Orthosiphon stamineus leaf extract were suggested. Parsley and dill leave also display antibacterial activity with natural microflora, coliforms, yeast, molds and S. Cheese aureus [68]. [69]. Coffee includes many phenolic compounds that are known to be antibacterial [69], including caffeic acid, chlorogenic acid and protocatechnic acid. The methylated derivative xanthine alkaloid found in plant species is 
International Journal of Agriculture and Environmental Research

ISSN: 2455-6939

Volume: 07, Issue: 01 "January-February 2021"

caffeine (1.3.7-trimethylexanthin). Coffee caffeine has demonstrated a significant inhibition of $\mathrm{E}$ development. O157:H7 coli in 0.5 percent [70] concentration. In the same way, the polyphenols of tea have also been found to be antigal-microbial to the againt Gram-positive and gramnegative bacteria (epicatechin, catechin, cafeine, chlorogenic acid, gallic acid, theobromine, theophylline, gallocatechin, gallochin gallate, catechin gallate, epicatechin gallate and theaflavin). Crude watersolution arrowroot (Puerariae radix) Tea's antimicrobial activity against E. O157:H7 coli, S entrique, L. and S. Monocytogenes. It was notified to aureus [71]. Catechins may be caused by the antimicrobial functioning of arrowroot tea. Catechins in green tea extract, gallate epigallocatechin and epigallocatechin have demonstrated good antimicrobial activity because their structure contains galloyl motivation [72]. Green tea has also been reported to have essential antifouling activity in a number of pathogens including resistant strains such as staphylococci resistant to methicillin and ciprofloxacin, enterococcal vancomycin resistant and Pseudomonas aeruginosa resistant to ciprofloxacin [39]. This allows for the extraction of phenolic compounds from various seeds and leaves and can be used to improve food protection and increase the shelf life of food products.

\section{FACTORS INFLUENCING THE ANTIMICROBIAL ACTIVITY OF NATURAL PRODUCTS}

Numerous factors including the botanical source, harvest date, stage of growth, and method of extraction may influence the antimicrobial activity of natural compounds, as well as their composition, structure, and functional groups [9]. Moreover, the use of natural ingredients as food preservatives often plays a key role in food components and additives which can interfere with natural antimicrobial compounds. For example, the effect of antimicrobial peptides in food systems can be decreased without special cationic antimicrobal peptide binding to negatively charged food particles [76]. Moreover, most studies have been performed in vitro with the use of microbiological media for antimicrobial effects of natural compounds $[8,9,56]$. The effectiveness of natural compounds in complex food systems is, thus, less known. Food is not sterile, so that a mixed microbial community will affect results obtained through antagonistic experiments. Hot-treats needed to destroy the microbial flora in foods may also alter food-matrix chemical composition and therefore affect natural antimicrobial performance. So, more information was required to ensure the efficacy of natural antimicrobials in the field of interaction between natural antimicrobials with food components. In application of natural antimicrobials to food items, the impacts of food ingredients, manufacturing and storage conditions must be taken into account [9, $16,37,76]$. Thyme, clove and pimento EOs, for instance, were tested in peptone water and found to be effective against L. monocytogenes. Monocytogenes. The effectiveness of EOs was therefore diminished by their interaction with food components when used with the food system [37]. EOs showed antibacterial properties against L monocytogenes, Sin in vitro studies. E, typhimurium. 
International Journal of Agriculture and Environmental Research

ISSN: 2455-6939

Volume: 07, Issue: 01 "January-February 2021"

Coli, B. Coli. And S, and Cereus. [122]. aureus. In contrast to laboratory concentrations, however, higher concentrations of EOs were found to be needed in foods. In the general sense, higher concentrations of natural antimicrobials may be needed for the same effect in food systems than in laboratory media [36]. Moreover, natural antimicrobial combinations, such as combinations of EOs or organic acids, may be more effective in food than in single EO $[16,89]$. The $\mathrm{pH}$ value also has a big effect on the output of natural antimicrobials. The low $\mathrm{pH}$ (around 5) seemed to have the greatest influence on the increase in the antimicrobial activity of EOs against L. [16] monocytogenes. This low $\mathrm{pH}$ value may increase the hydrophobicity of EOs, which could facilitate the dissolution of the target bacteria's cell membrane lipids. The development of bacteriocinresistant bacterias, conditions that destabilize protein biomass such as proteases and/or oxidation processes, bindings with food-related components or food-additive inactivation, poor solubility and unevenness may be influenced by various factors, amongst which are the development, Food delivery plus food $\mathrm{pH}[9,123]$ in the food matrix. Bacteriocin tolerance in target microbes can be minimized through the hinder application of bacteriocins in conjunction with other bacteriocins or naturally preserved [124]. In the Appam Batter and Pickles Pickles Lactobacillus isolates, nisin individually and in combinations, for example, the anti-microbial effective effect of bacteriocin LABB and LABP was assessedIn combination with nisin or in combination with other bacteriocins, bacteriocins LABB and LABP were shown to be more active than alone and these dual bacteriocin combinations were also able to inhibit E. coli and Pseudomonas sp. [124].

\section{EXTRACTION METHODS AND PURIFICATION}

Recently, the use of natural antimicrobial agents has concentrated on extending the shelf life of foodstuffs, decreasing or removing pathogenic bacteria and increasing the overall quality of foodstuffs $[8,16,125]$. However, successful extraction and purification methods are needed for commercial applications of natural antimicrobial substances. Most commonly developed by SD (steam distillation) and HD (hydro distillation) methods are commercially based plant-origin antimicrobials, and different ways also including SFE (supercritical fluid extraction) give high content and improved mass transfer speeds. The management of parameters like the temperature and the pressure, however, leads to various components being extracted when a specific component is required. More available commercial products are also available in the bioengineering of EO components [36]. Antimicrobial processes in plants are mainly responsible for EOs and other plant extracts. These compounds can be extracted by different techniques, including such steam, cold, dry and vacuum distillation, from plants and spices. [8, 110Popular extraction procedures require chemical or heat treatments that can modify or trigger hazardous compounds to the active ingredients, to their total material, functionality or natural qualities [126, 127]. The direct extraction method can be used to obtain extracts from fruits and vegetables. Direct extraction is a quick and secure process, which prevents the native structure of the active 
International Journal of Agriculture and Environmental Research

ISSN: 2455-6939

Volume: 07, Issue: 01 "January-February 2021"

ingredients from being altered or damaged. For example, direct extract from guava and xoconostle pears were found to be effective against Salmonella spp. and E. coli O157:H7 respectively [43, 44]. Direct extract can be obtained mechanically from fruits and vegetables without processing chemical materials, heating or concentration. Direct extracts can also be safely used for foodstuffs. Another basic process for extracting water-soluble phenolic compounds from seed and leaves is the extraction of water [61]. Heat therapy was observed for antimicrobial activity and an improvement in acidity, phenolics total and individual phenolic compounds in the treatment of water-soluble muscadine seed extracts [61]. Alternative therapies such as ultra-high-temperature treatment, farinfrared radiation and/or enzyme treatment can optimize the release of low-molecular-weight polymer-form compounds, thereby reducing antimicrobial efficacy [61]. Direct extract or juice mining therefore seems to be the most promising way of avoiding future changes in the composition of the natural antimicrobial compound.

\section{SUMMARY}

The secondary metabolites that live organisms, including plants, animals, and microorganisms, can generate are natural antimicrobials. Only in the last 30 years has the antimicrobial activity of these metabolites been scientifically verified. Herbs and spices, which normally contain EOs, are the most common plants used as natural antimicrobials by the food industry to inhibit foodborne pathogens and prolong the shelf life of foods. Different factors may affect the antimicrobial effect of natural products, including the botanical source, harvest time, development stage and method of extraction. These natural antimicrobial compounds could also be caused by food materials, processing, and storage in food applications, and could therefore require higher concentrations than those used in laboratory media. The addition of natural antimicrobials to food products, on the other hand, can affect the sensory properties of the final product. The challenge for realistic application of natural antimicrobials is therefore to create an optimal combination of low doses of antimicrobial agents that could preserve product protection and prolong shelf life but reduce undesirable taste and sensory changes associated with high concentrations of natural antimicrobials being applied. However, in commercial food products, only a limited number of natural antimicrobials are used. While a large number of natural antimicrobials are identified nowadays, due to higher costs compared to chemical preservatives, only a small number of natural antimicrobial compounds are currently used in commercial applications. In order to be used in food systems, further research on potential low-cost production of natural products is therefore needed. In most cases, to be tested or applied to food products, natural antimicrobials are extracted and purified. A minimally processed extraction method, such as direct extraction, appears to be a promising method for avoiding potential modification or degradation of active ingredients. Natural antimicrobials tend to be the most effective response to many concerns regarding food safety and food quality. Therefore, further investigations into food products with natural antimicrobials would 
International Journal of Agriculture and Environmental Research

ISSN: 2455-6939

Volume: 07, Issue: 01 "January-February 2021"

be expected in the future, especially in the areas of synergistic efficacy and optimum concentrations.

\section{REFERENCES}

[1] Koehn FE, Carter GT. The evolving role of natural products in drug discovery. Nature Reviews Drug Discovery 2005; 4:206.

[2] Bhatnagar I, Kim S-K. Immense essence of excellence: marine microbial bioactive compounds. Marine Drugs 2010; 8:2673.

[3] Gyawali R, Ibrahim SA. Impact of plant derivatives on the growth of foodborne pathogens and the functionality of probiotics. Applied Microbiology and Biotechnology 2012:1.

[4] Lv F, Liang H, Yuan Q, Li C. In vitro antimicrobial effects and mechanism of action of selected plant essential oil combinations against four food-related microorganisms. Food Research International 2011;44:3057.

[5] Sofos JN. Challenges to meat safety in the 21st century. Meat Science 2008;78:3.

[6] Mathew AG, Cissell R, Liamthong S. Antibiotic resistance in bacteria associated with food animals: a United States perspective of livestock production. Foodborne Pathogens and Disease 2007;4:115.

[7] Ngwoke KG, Odimegwu DC, Esimone CO. Antimicrobial natural products. In: MendezVilas A, editor. Science against microbial pathogens: communicating current research and technology advances. Badajoz, Spain: FORMATEX; 2011, p. 1011.

[8] Tajkarimi M, Ibrahim S, Cliver D. Antimicrobial herb and spice compounds in food. Food Control 2010;21:1199.

[9] Tiwari BK, Valdramidis VP, O’Donnell CP, Muthukumarappan K, Bourke P, Cullen P. Application of natural antimicrobials for food preservation. Journal of Agricultural and Food Chemistry 2009;57:5987.

[10] Aires A, Mota V, Saavedra M, Rosa E, Bennett R. The antimicrobial effects of glucosinolates and their respective enzymatic hydrolysis products on bacteria isolated from the human intestinal tract. Journal of Applied Microbiology 2009;106:2086.

[11] Fattouch S, Caboni P, Coroneo V, Tuberoso CI, Angioni A, Dessi S, et al. Antimicrobial activity of Tunisian quince (Cydonia oblonga Miller) pulp and peel polyphenolic extracts. Journal of Agricultural and Food Chemistry 2007;55:963. 
International Journal of Agriculture and Environmental Research

ISSN: 2455-6939

Volume: 07, Issue: 01 "January-February 2021"

[12] Lanciotti R, Gianotti A, Patrignani F, Belletti N, Guerzoni M, Gardini F. Use of natural aroma compounds to improve shelf-life and safety of minimally processed fruits. Trends in Food Science \& Technology 2004;15:201.

[13] Srinivasan D, Nathan S, Suresh T, Lakshmana Perumalsamy P. Antimicrobial activity of certain Indian medicinal plants used in folkloric medicine. Journal of Ethnopharmacology 2001;74:217.

[14] Shan B, Cai Y-Z, Brooks JD, Corke H. The in vitro antibacterial activity of dietary spice and medicinal herb extracts. International Journal of Food Microbiology 2007;117:112.

[15] Hafidh RR, Abdulamir AS, Vern LS, Bakar FA, Abas F, Jahanshiri F, et al. Inhibition of Growth of Highly Resistant Bacterial and Fungal Pathogens by a Natural Product. The Open Microbiology Journal 2011;5:96.

[16] Gutierrez J, Barry-Ryan C, Bourke P. The antimicrobial efficacy of plant essential oil combinations and interactions with food ingredients. International Journal of Food Microbiology 2008;124:91.

[17] Lopes-Lutz D, Alviano DS, Alviano CS, Kolodziejczyk PP. Screening of chemical composition, antimicrobial and antioxidant activities of Artemisia essential oils. Phytochemistry 2008;69:1732.

[18] Holley RA, Patel D. Improvement in shelf-life and safety of perishable foods by plant essential oils and smoke antimicrobials. Food Microbiology 2005;22:273.

[19] Nguefack J, Nguikwie S, Fotio D, Dongmo B, Zollo PA, Leth V, et al. Fungicidal potential of essential oils and fractions from Cymbopogoncitratus, Ocimumgratissimum and Thymus vulgaris to control Alternariapadwickii and Bipolarisoryzae, two seed-borne fungi of rice (Oryza Sativa L.). Journal of Essential Oil Research 2007;19:581.

[20] Mandalari G, Bennett R, Bisignano G, Trombetta D, Saija A, Faulds C, et al. Antimicrobial activity of flavonoids extracted from bergamot (Citrus bergamiaRisso) peel, a byproduct of the essential oil industry. Journal of Applied Microbiology 2007;103:2056.

[21] Cushnie T, Lamb AJ. Antimicrobial activity of flavonoids. International Journal of Antimicrobial Agents 2005;26:343.

[22] Bahraminejad S, Asenstorfer RE, Riley IT, Schultz C. Analysis of the antimicrobial activity of flavonoids and saponins isolated from the shoots of oats (Avena sativa $\mathrm{L}$.). Journal of Phytopathology 2007;156:1. 
International Journal of Agriculture and Environmental Research

ISSN: 2455-6939

Volume: 07, Issue: 01 "January-February 2021"

[23] Kuete V, TsafackMbaveng A, Tsaffack M, PenlapBeng V, Etoa FX, Nkengfack AE, et al. Antitumor, antioxidant and antimicrobial activities of Bersamaengleriana(Melianthaceae). Journal of Ethnopharmacology 2008;115:494.

[24] Musyimi D, Ogur J, Muema P. Phytochemical compounds and antimicrobial activity of extracts of aspilia plant (Aspiliamossambicensis)(Oliv) Wild. International Journal of Botany 2008;4.

[25] Bones AM, Rossiter JT. The myrosinase-glucosinolate system, its organisation and biochemistry. Physiologia Plantarum 2006;97:194.

[26] Du W-X, Avena-Bustillos RJ, Hua SST, McHugh TH. Antimicrobial volatile essential oils in edible films for food safety. Science 2011:1124.

[27] Du W-X, Olsen CW, Avena-Bustillos RJ, McHugh TH, Levin CE, Mandrell R, et al. Antibacterial effects of allspice, garlic, and oregano essential oils in tomato films determined by overlay and vapor-phase methods. Journal of Food Science 2009;74:M390.

[28] Sandasi M, Leonard C, Viljoen A. The effect of five common essential oil components on Listeria monocytogenes biofilms. Food Control 2008;19:1070.

[29] Raybaudi-Massilia RM, Mosqueda-Melgar J, Martin-Belloso O. Antimicrobial activity of essential oils on Salmonella enteritidis, Escherichia coli, and Listeria innocuain fruit juices. Journal of Food Protection® 2006;69:1579.

[30] Turgis M, Borsa J, Millette M, Salmieri S, Lacroix M. Effect of selected plant essential oils or their constituents and modified atmosphere packaging on the radiosensitivity of Escherichia coli O157: H7 and Salmonella Typhi in ground beef. Journal of Food Protection® 2008;71:516.

[31] Angioni A, Barra A, Cereti E, Barile D, Coïsson JD, Arlorio M, et al. Chemical composition, plant genetic differences, antimicrobial and antifungal activity investigation of the essential oil of Rosmarinus officinalis L. Journal of Agricultural and Food Chemistry 2004;52:3530.

[32] Proestos C, Boziaris IS, Kapsokefalou M, Komaitis M. Natural antioxidant constituents from selected aromatic plants and their antimicrobial activity against selected pathogenic microorganisms. Food Technology and Biotechnology 2008;46:151. 
International Journal of Agriculture and Environmental Research

ISSN: 2455-6939

Volume: 07, Issue: 01 "January-February 2021"

[33] Nanasombat S, Lohasupthawee P. Antibacterial activity of crude ethanolic extracts and essential oils of spices against Salmonellae and other enterobacteria. KMITL Science and Technology Journal 2005;5:527.

[34] Burt SA, Reinders RD. Antibacterial activity of selected plant essential oils against Escherichia coli O157: H7. Letters in applied microbiology 2003;36:162.

[35] Dorman H, Deans S. Antimicrobial agents from plants: antibacterial activity of plant volatile oils. Journal of Applied Microbiology 2008;88:308.

[36] Burt S. Essential oils: their antibacterial properties and potential applications in foods-a review. International Journal of Food Microbiology 2004;94:223.

[37] Singh A, Singh R, Bhunia A, Singh N. Efficacy of plant essential oils as antimicrobial agents against Listeria monocytogenes in hotdogs. LWT-Food Science and Technology 2003;36:787.

[38] Dorantes L, Colmenero R, Hernandez H, Mota L, Jaramillo ME, Fernandez E, et al. Inhibition of growth of some foodborne pathogenic bacteria by Capsicum аппиит extracts. International Journal of Food Microbiology 2000;57:125.

[39] Lee Y-L, Cesario T, Wang Y, Shanbrom E, Thrupp L. Antibacterial activity of vegetables and juices. Nutrition 2003;19:994.

[40] Ibrahim SA, Bor T, Song D, Tajkarimi M. Survival and growth characteristics of Escherichia coli O157: H7 in pomegranatecarrot and pomegranate-apple blend juices. Food and Nutrition 2011;2:844.

[41] Al-Zoreky NS. Antimicrobial activity of pomegranate (PunicagranatumL.) fruit peels. International Journal of Food Microbiology 2009;134:244.

[42] Özkan G, Sagdiç O, GöktürkBaydar N, Kurumahmutoglu Z. Antibacterial activities and total phenolic contents of grape pomace extracts. Journal of the Science of Food and Agriculture 2004;84:1807.

[43] Ibrahim SA, Yang G, Song D, Tom S. Antimicrobial effect of guava on Escherichia coli O157: H7 and Salmonella typhimurium in liquid medium. International Journal of Food Properties 2011;14:102.

[44] Hayek SA, Ibrahim SA. Antimicrobial Activity of Xoconostle Pears (Opuntiamatudae) against Escherichia coli O157: H7 in Laboratory Medium. International Journal of Microbiology 2012;2012. 
International Journal of Agriculture and Environmental Research

ISSN: 2455-6939

Volume: 07, Issue: 01 "January-February 2021"

[45] Feugang JM, Konarski P, Zou D, Stintzing FC, Zou C. Nutritional and medicinal use of cactus pear (Opuntia spp.) cladodes and fruits. Frontiers in Bioscience 2006;11:2574.

[46] GENTILE C, Tesoriere L, ALlEGRA M, Livrea M, D'AlESSIO P. Antioxidant Betalains from Cactus Pear (Opuntiaficus-indica) Inhibit Endothelial ICAM-1 Expression. Annals of the New York Academy of Sciences 2004;1028:481.

[47] Azeredo H. Betalains: properties, sources, applications, and stability-a review. International Journal of Food Science \& Technology 2009;44:2365.

[48] Careaga M, Fernández E, Dorantes L, Mota L, Jaramillo ME, Hernandez-Sanchez H. Antibacterial activity of Capsicum extract against Salmonella typhimurium and Pseudomonas aeruginosa inoculated in raw beef meat. International Journal of Food Microbiology 2003;83:331.

[49] Belguith H, Kthiri F, Ben Ammar A, Jaafoura H, Ben Hamida J, Landoulsi A. Morphological and Biochemical Changes of Salmonella hadarExposed to Aqueous Garlic Extract. International Journal of Morphology 2009;27:705.

[50] Ankri S, Mirelman D. Antimicrobial properties of allicin from garlic. Microbes and Infection 1999;1:125.

[51] Avato P, Tursi F, Vitali C, Miccolis V, Candido V. Allylsulfide constituents of garlic volatile oil as antimicrobial agents. Phytomedicine 2000;7:239.

[52] Indu MN, Hatha AAM, Abirosh C, Harsha U, Vivekanandan G. Antimicrobial activity of some of the south-Indian spices against serotypes of Escherichia coli, Salmonella, Listeria monocytogenes and Aeromonashydrophila. Brazilian Journal of Microbiology 2006;37:153.

[53] Mau J-L, Chen C-P, Hsieh P-C. Antimicrobial effect of extracts from Chinese chive, cinnamon, and cornifructus. Journal of Agricultural and Food Chemistry 2001;49:183.

[54] Ibrahim S, Tse T, Yang H, Fraser A. Antibacterial activity of a crude chive extract against Salmonella in culture medium, beef broth and chicken broth. Food Protection Trends 2009;29:155.

[55] Dubey A, Mishra N, Singh N. Antimicrobial activity of some selected vegetables. International Journal of Applied Biology and Pharmaceutical Technology 2010;1:994.

[56] Delaquis PJ, Stanich K, Girard B, Mazza G. Antimicrobial activity of individual and mixed fractions of dill, cilantro, coriander and eucalyptus essential oils. International Journal of Food Microbiology 2002;74:101. 
International Journal of Agriculture and Environmental Research

ISSN: 2455-6939

Volume: 07, Issue: 01 "January-February 2021"

[57] Ahn J, Grun IU, Mustapha A. Antimicrobial and antioxidant activities of natural extracts in vitro and in ground beef. Journal of Food Protection® 2004;67:148.

[58] Rababah TM, Navam S, Horax R. Total phenolics and antioxidant activities of fenugreek, green tea, black tea, grape seed, ginger, rosemary, gotu kola, and ginkgo extracts, vitamin E, and tert-butylhydroquinone. Journal of Agricultural and Food Chemistry 2004;52:5183.

[59] Theivendran S, Hettiarachchy NS, Johnson MG. Inhibition of Listeria monocytogenes by nisin combined with grape seed extract or green tea extract in soy protein film coated on turkey frankfurters. Journal of Food Science 2006;71:M39.

[60] Gadang VP, Hettiarachchy NS, Johnson MG, Owens C. Evaluation of antibacterial activity of whey protein isolate coating incorporated with nisin, grape seed extract, malic acid, and EDTA on a turkey frankfurter system. Journal of Food Science 2008;73:M389.

[61] Kim T, Weng W, Stojanovic J, Lu Y, Jung Y, Silva J. Antimicrobial effect of watersoluble muscadine seed extracts on Escherichia coli O157: H7. Journal of Food Protection 2008;71:1465.

[62] Markin D, Duek L, Berdicevsky I. In vitro antimicrobial activity of olive leaves. Mycoses 2008;46:132.

[63] Pereira AP, Ferreira IC, Marcelino F, Valentão P, Andrade PB, Seabra R, et al. Phenolic compounds and antimicrobial activity of olive (Oleaeuropaea L. Cv. Cobrançosa) leaves. Molecules 2007;12:1153.

[64] Tahir L, Khan N. Antibacterial potentialof crude leaf, fruit and flower extracts of TagetesMinuta L. Journal of Public Health and Biological Sciences 2012;1:74.

[65] Thiem B, Goślińska O. Antimicrobial activity of Rubuschamaemorusleaves. Fitoterapia2004;75:93.

[66] Somchit MN, Reezal I, Nur IE, Mutalib AR. In vitro antimicrobial activity of ethanol and water extracts of Cassia alata. Journal of Ethnopharmacology 2003;84:1.

[67] Ho C-H, Noryati I, Sulaiman S-F, Rosma A. In vitro antibacterial and antioxidant activities of OrthosiphonstamineusBenth. extracts against food-borne bacteria. Food Chemistry 2010;122:1168.

[68] Wahba NM, Ahmed AS, Ebraheim ZZ. Antimicrobial effects of pepper, parsley, and dill and their roles in the microbiological quality enhancement of traditional Egyptian Kareish cheese. Foodborne Pathogens and Disease 2010;7:411. 
International Journal of Agriculture and Environmental Research

ISSN: 2455-6939

Volume: 07, Issue: 01 "January-February 2021"

[69] Dogasaki C, Shindo T, Furuhata K, Fukuyama M. [Identification of chemical structure of antibacterial components against Legionella pneumophila in a coffee beverage]. Yakugakuzasshi: Journal of the Pharmaceutical Society of Japan 2002;122:487.

[70] Ibrahim SA, Salameh MM, Phetsomphou S, Yang H, Seo CW. Application of caffeine, 1, 3, 7-trimethylxanthine, to control Escherichia coli O157: H7. Food Chemistry 2006;99:645.

[71] Kim S, Fung DYC. Antibacterial effect of crude water-soluble arrowroot (Puerariae radix) tea extracts on foodborne pathogens in liquid medium. Letters in Applied Microbiology 2004;39:319.

[72] Shimamura T, Zhao W-H, Hu Z-Q. Mechanism of action and potential for use of tea catechin as an antiinfective agent. Anti- Infective Agents in Medicinal Chemistry (Formerly Current Medicinal Chemistry-Anti-Infective Agents) 2007;6:57.

[73] Hoskin DW, Ramamoorthy A. Studies on anticancer activities of antimicrobial peptides. Biochimica et BiophysicaActa (BBA)-Biomembranes2008;1778:357.

[74] Burrowes OJ, Hadjicharalambous C, Diamond G, LEE T-C. Evaluation of antimicrobial spectrum and cytotoxic activity of pleurocidin for food applications. Journal of Food Science 2004;69:FMS66.

[75] Cole AM, Darouiche RO, Legarda D, Connell N, Diamond G. Characterization of a fish antimicrobial peptide: gene expression, subcellular localization, and spectrum of activity. Antimicrobial Agents and Chemotherapy 2000;44:2039.

[76] Potter R, Truelstrup Hansen L, Gill TA. Inhibition of foodborne bacteria by native and modified protamine: Importance of electrostatic interactions. International Journal of Food Microbiology 2005;103:23.

[77] Humblot V, Yala J-F, Thebault P, Boukerma K, Héquet A, Berjeaud J-M, et al. The antibacterial activity of Magaininlimmobilized onto mixed thiols self-assembled monolayers. Biomaterials 2009;30:3503.

[78] Seifu E, Buys EM, Donkin E. Significance of the lactoperoxidase system in the dairy industry and its potential applications: a review. Trends in Food Science \& Technology 2005;16:137.

[79] Lönnerdal B. Nutritional and physiologic significance of human milk proteins. The American journal of clinical nutrition 2003;77:1537S. 
International Journal of Agriculture and Environmental Research

ISSN: 2455-6939

Volume: 07, Issue: 01 "January-February 2021"

[80] Murdock CA, Cleveland J, Matthews KR, Chikindas ML. The synergistic effect of nisin and lactoferrin on the inhibition of Listeria monocytogenes and Escherichia coli O157: H7. Letters in Applied Microbiology 2006;44:255.

[81] van den Berg WCM, Düsterhöft EM, Smit G. Gouda and related cheeses In: Fox PF, McSweeney PLH, Cogan TM, Guinee TP, editors. Cheese: Chemistry, physics and microbiology. 3 ed. London, UK: Elsevier Academic Press; 2004, p. 103.

[82] Ben-Shalom N, Ardi R, Pinto R, Aki C, Fallik E. Controlling gray mould caused by Botrytis cinereain cucumber plants by means of chitosan. Crop Protection 2003;22:285.

[83] Fernandes JC, Tavaria FK, Soares JC, Ramos ÓS, João Monteiro M, Pintado ME, et al. Antimicrobial effects of chitosans and chitooligosaccharides, upon Staphylococcus aureus and Escherichia coli, in food model systems. Food Microbiology 2008;25:922.

[84] Desbois AP, Smith VJ. Antibacterial free fatty acids: activities, mechanisms of action and biotechnological potential. Applied Microbiology and Biotechnology 2010;85:1629.

[85] Shin SY, Bajpai VK, Kim HR, Kang SC. Antibacterial activity of bioconvertedeicosapentaenoic (EPA) and docosahexaenoic acid (DHA) against foodborne pathogenic bacteria. International Journal of Food Microbiology 2007;113:233.

[86] Demain A. Pharmaceutically active secondary metabolites of microorganisms. Applied Microbiology and Biotechnology 1999;52:455.

[87] Nes IF, Johnsborg O. Exploration of antimicrobial potential in LAB by genomics. Current Opinion in Biotechnology 2004;15:100.

[88] Skrivanova E, Marounek M, Benda V, Brezina P. Susceptibility of Escherichia coli, Salmonella sp. and Clostridium perfringens to organic acids and monolaurin. VeterinarniMedicina2006;51:81.

[89] Raftari M. Antibacterial activity of organic acids on the growth of selected bacteria in meat samples. Food Science and Technology. Malaysia: Universiti Putra Malaysia; 2009, p. 111.

[90] Tajkarimi M, Ibrahim SA. Antimicrobial activity of ascorbic acid alone or in combination with lactic acid on Escherichia coli O157: H7 in laboratory medium and carrot juice. Food Control 2011;22:801. 
International Journal of Agriculture and Environmental Research

ISSN: 2455-6939

Volume: 07, Issue: 01 "January-February 2021"

[91] Ibrahim SA, Yang H, Seo CW. Antimicrobial activity of lactic acid and copper on growth of Salmonella and Escherichia coli O157: $\mathrm{H} 7$ in laboratory medium and carrot juice. Food Chemistry 2008;109:137.

[92] Gyawali R, Ibrahim SA, Abu Hasfa SH, Smqadri SQ, Haik Y. Antimicrobial activity of copper alone and in combination with lactic acid against Escherichia coli O157: H7 in laboratory medium and on the surface of lettuce and tomatoes. Journal of Pathogens 2011;2011.

[93] Lindgren SE, Dobrogosz WJ. Antagonistic activities of lactic acid bacteria in food and feed fermentations. FEMS Microbiology Letters 1990;87:149.

[94] Ouwehand AC, Vesterlund S. Antimicrobial components from lactic acid bacteria. In: Salminen S, Wright Av, editors. Lactic Acid Bacteria: Microbiological and Functional Aspects, . 3 ed. New York: Marcel Dekker, Inc.; 2004, p. 375.

[95] Choi O, Hu Z. Size dependent and reactive oxygen species related nanosilver toxicity to nitrifying bacteria. Environmental Science \& Technology 2008;42:4583.

[96] Reid G. Probiotic lactobacilli for urogenital health in women. Journal of Clinical Gastroenterology 2008;42:S234.

[97] Šušković J, Kos B, Beganović J, LebošPavunc A, Habjanič K, Matošić S. Antimicrobial activity-the most important property of probiotic and starter lactic acid bacteria. Food Technology and Biotechnology 2010;48:296.

[98] Savadogo A, Ouattara A, Bassole H, Traore SA. Bacteriocins and lactic acid bacteria-a minireview. African Journal of Biotechnology 2009;5.

[99] Gálvez A, López RL, Abriouel H, Valdivia E, Omar NB. Application of bacteriocins in the control of foodborne pathogenic and spoilage bacteria. Critical Reviews in Biotechnology 2008;28:125.

[100] Falla TJ, Karunaratne DN, Hancock RE. Mode of action of the antimicrobial peptide indolicidin. Journal of Biological Chemistry 1996;271:19298.

[101] Hancock RE, Lehrer R. Cationic peptides: a new source of antibiotics. Trends in Biotechnology 1998;16:82.

[102] Papagianni M, Anastasiadou S. Pediocins: The bacteriocins of pediococci. Sources, production, properties and applications. Microbial Cell Factories 2009;8:3. 
International Journal of Agriculture and Environmental Research

ISSN: 2455-6939

Volume: 07, Issue: 01 "January-February 2021"

[103] Bhunia A, Johnson M, Ray B. Purification, characterization and antimicrobial spectrum of a bacteriocin produced by Pediococcusacidilactici. Journal of Applied Microbiology 1988;65:261.

[104] de Oliveira TM, de Fátima Ferreira Soares N, Pereira RM, de Freitas Fraga K. Development and evaluation of antimicrobial natamycin-incorporated film in gorgonzola cheese conservation. Packaging Technology and Science 2007;20:147.

[105] Doleyres Y, Beck P, Vollenweider S, Lacroix C. Production of 3hydroxypropionaldehyde using a two-step process with Lactobacillus reuteri. Applied Microbiology and Biotechnology 2005;68:467.

[106] Gänzle MG, Vogel RF. Studies on the mode of action of reutericyclin. Applied and Environmental Microbiology 2003;69:1305.

[107] Axelsson LT, Chung TC, Dobrogosz WJ, Lindgren SE. Production of a broad spectrum antimicrobial substance by Lactobacillus reuteri. Microbial Ecology in Health and Disease 1989;2:131.

[108] Arqués JL, Fernández J, Gaya P, Nuñez M, Rodríguez E, Medina M. Antimicrobial activity of reuterin in combination with nisin against food-borne pathogens. International Journal of Food Microbiology 2004;95:225.

[109] Ciocan D, Ioan B. Plant products as antimicrobial agents. AnaleleStiintifice ale Universitatii" AlexandruIoanCuza" din Iasi Sec II a GeneticasiBiologieMoleculara $2007 ; 8$.

[110] Bajpai VK, Rahman A, Dung NT, Huh MK, Kang SC. In vitro inhibition of food spoilage and foodborne pathogenic bacteria by essential oil and leaf extracts of Magnolia lilifloraDesr. Journal of Food Science 2008;73:M314.

[111] Tafesh A, Najami N, Jadoun J, Halahlih F, Riepl H, Azaizeh H. Synergistic antibacterial effects of polyphenolic compounds from olive mill wastewater. Evidence-Based Complementary and Alternative Medicine 2011;2011.

[112] Delaquis P, Mazza G. Antimicrobial properties of isothiocyanates in food preservation. Food Technology 1995;49:73.

[113] Brogden KA. Antimicrobial peptides: pore formers or metabolic inhibitors in bacteria? Nature Reviews Microbiology 2005;3:238. 
International Journal of Agriculture and Environmental Research

ISSN: 2455-6939

Volume: 07, Issue: 01 "January-February 2021"

[114] Yoshida K, Mukai Y, Niidome T, Takashi C, Tokunaga Y, Hatakeyama T, et al. Interaction of pleurocidin and its analogs with phospholipid membrane and their antibacterial activity. The Journal of Peptide Research 2002;57:119.

[115] Kankaanpa PE, Salminen SJ, Isolauri E, Lee YK. The influence of polyunsaturated fatty acids on probiotic growth and adhesion. FEMS Microbiology Letters 2001;194:149.

[116] Driessen AJ, van den Hooven HW, Kuiper W, Van de Camp M, Sahl H-G, Konings RN, et al. Mechanistic studies of lantibiotic-induced permeabilization of phospholipid vesicles. Biochemistry 1995;34:1606.

[117] Lee D, Heinz V, Knorr D. Effects of combination treatments of nisin and high-intensity ultrasound with high pressure on the microbial inactivation in liquid whole egg. Innovative Food Science \& Emerging Technologies 2003;4:387.

[118] Helander IM, Nurmiaho-Lassila E-L, Ahvenainen R, Rhoades J, Roller S. Chitosan disrupts the barrier properties of the outer membrane of Gram-negative bacteria. International Journal of Food Microbiology 2001;71:235.

[119] Crandall AD, Montville TJ. Nisin resistance in Listeria monocytogenes ATCC 700302 is a complex phenotype. Applied and Environmental Microbiology 1998;64:231.

[120] De Vuyst L, Leroy F. Bacteriocins from lactic acid bacteria: production, purification, and food applications. Journal of Molecular Microbiology and Biotechnology 2007;13:194.

[121] Chen H, Hoover DG. Bacteriocins and their food applications. Comprehensive Reviews in Food Science and Food Safety 2006;2:82.

[122] Cosentino S, Tuberoso CIG, Pisano B, Satta M, Mascia V, Arzedi E, et al. In-vitro antimicrobial activity and chemical composition of Sardinian Thymus essential oils. Letters in Applied Microbiology 1999;29:130.

[123] Bastos MdCdF, Ceotto H. 5 Bacterial Antimicrobial Peptides and Food Preservation. In: Rai M, Chikindas M, editors. Natural Antimicrobials in Food Safety and Quality. London, UK.: CAB International; 2011, p. 62.

[124] Settanni L, Corsetti A. Application of bacteriocins in vegetable food biopreservation. International Journal of Food Microbiology 2008;121:123.

[125] Lu S, Xia Q. Effects of combined treatments with modified-atmosphere packaging on shelf-life improvement of food products. In: Bhat R, Alias AK, Paliyath G, editors. Progress in Food Preservation. West Sussex, UK: Wiley-Blackwell; 2012, p. 67. 
[126] Beta T, Rooney L, Marovatsanga L, Taylor J. Effect of chemical treatments on polyphenols and malt quality in sorghum. Journal of Cereal Science 2000;31:295.

[127] Lin Y-C, Chou C-C. Effect of heat treatment on total phenolic and anthocyanin contents as well as antioxidant activity of the extract from Aspergillus awamori-fermented black soybeans, a healthy food ingredient. International Journal of Food Sciences and Nutrition 2009;60:627.

[128] Niino H, Sakane I, Okanoya K, Kuribayashi S, Kinugasa H. Determination of mechanism of flock sediment formation in tea beverages. Journal of Agricultural and Food Chemistry 2005;53:3995.

[129] Jeong S-M, Kim S-Y, Kim D-R, Jo S-C, Nam K, Ahn D, et al. Effect of heat treatment on the antioxidant activity of extracts from citrus peels. Journal of Agricultural and Food Chemistry 2004;52:3389. 